\title{
Chronic Lithium Treatment Attenuates Intracellular Calcium Mobilization
}

\author{
Michael J Wasserman 1,2, Timothy W Corson ${ }^{1,5}$, David Sibony', Robert G Cooke ${ }^{3}$, Sagar V Parikh ${ }^{3}$, \\ Peter S Pennefather ${ }^{2,4}$, Peter $P \mathbf{L i}^{1,2,3}$ and Jerry J Warsh*, 1,2,3,5 \\ 'Laboratory of Cellular and Molecular Pathophysiology, Centre for Addiction and Mental Health, University of Toronto, Toronto, ON, Canada; \\ ${ }^{2}$ Department of Pharmacology, University of Toronto, Toronto, ON, Canada; ${ }^{3}$ Department of Psychiatry, University of Toronto, Toronto, ON, \\ Canada; ${ }^{4}$ Faculty of Pharmacy, University of Toronto, Toronto, ON, Canada; ${ }^{5}$ Institute of Medical Science, University of Toronto, Toronto, ON, \\ Canada
}

\begin{abstract}
Elevated basal intracellular calcium $\left(\mathrm{Ca}^{2+}\right)$ levels $\left(\left[\mathrm{Ca}^{2+}\right]_{\mathrm{B}}\right)$ in B lymphoblast cell lines (BLCLs) from bipolar I disorder (BD-I) patients implicate altered $\mathrm{Ca}^{2+}$ homeostasis in this illness. Chronic lithium treatment affects key proteins modulating intracellular $\mathrm{Ca}^{2+}$ signaling. Thus, we sought to determine if chronic exposure to therapeutic lithium concentrations also modifies intracellular $\mathrm{Ca}^{2+}$ homeostasis in this surrogate cellular model of signal transduction disturbances in BD. BLCLs from BD-I $(N=26)$ and healthy subjects $(N=17)$ were regrown from frozen stock and incubated with $0.75 \mathrm{mM}$ lithium or vehicle for $24 \mathrm{~h}$ (acute) or 7 days (chronic). [Ca $\left.{ }^{2+}\right]_{B}$, lysophosphatidic acid (LPA)-stimulated $\mathrm{Ca}^{2+}$ mobilization $\left(\left[\mathrm{Ca}^{2+}\right]_{\mathrm{S}}\right.$ ), and thapsigargin-induced store-operated $\mathrm{Ca}^{2+}$ entry (SOCE) were determined using ratiometric fluorometry with Fura-2. Compared with vehicle, chronic lithium exposure resulted in significantly higher $\left[\mathrm{Ca}^{2+}\right]_{\mathrm{B}}$ $(\mathrm{F}=8.47 ; p=0.006)$ in BLCLs from BD-I and healthy subjects. However, peak LPA-stimulated $\left[\mathrm{Ca}^{2+}\right]_{\mathrm{s}}$ and SOCE were significantly reduced $(F=11 . I, p=0.002$ and $F=8.36, p=0.007$, respectively). Acute lithium exposure did not significantly affect measured parameters. In summary, the effect of chronic lithium to elevate $\left[\mathrm{Ca}^{2+}\right]_{\mathrm{B}}$ in BLCLs while attenuating both receptor-stimulated and SOCE components of intracellular $\mathrm{Ca}^{2+}$ mobilization in BLCLs suggests that modulation of intracellular $\mathrm{Ca}^{2+}$ homeostasis may be important to the therapeutic action of lithium.
\end{abstract}

Neuropsychopharmacology (2004) 29, 759-769, advance online publication, I 8 February 2004; doi: I 0.1 038/sj.npp. I 300400

Keywords: lithium; bipolar disorder; intracellular calcium mobilization; signal transduction; B lymphoblast; pathophysiology

\section{INTRODUCTION}

Lithium has been used in the management of bipolar disorder (BD) for over 50 years (Goodwin and Jamison, 1990), and despite its proven efficacy (Schou, 2001), the specific mechanism(s) by which it exerts its therapeutic effects in BD is still poorly understood (reviewed in Lenox et al, 1998; Manji et al, 2001). As the latency in onset of lithium's clinical action implicated plastic changes mediated through intracellular signaling processes, transcription regulation, and accompanying alterations in abundance and function of target proteins, intracellular signal transduction systems have come under closer scrutiny in search of the molecular basis of its therapeutic action in BD (Manji

\footnotetext{
* Correspondence: Jerry J Warsh, Laboratory of Cellular and Molecular Pathophysiology, Centre for Addiction and Mental Health, 250 College St., Room R20, Toronto, ON, Canada M5T IR8, Tel: + 4169794279 , Fax: + 416979 4730, E-mail: jerry_warsh@camh.net

Received 17 October 2003; revised 22 December 2003; accepted 31 December 2003

Online publication: 7 January 2004 at http://www.acnp.org/citations/ Npp0 1070403477/default.pdf
}

et al, 2001). Among these, the $\mathrm{Ca}^{2+}$ signaling system is of particular interest given its critical role in numerous cellular functions (for reviews see Ghosh and Greenberg, 1995; Berridge et al, 2000 and references therein).

Intracellular $\mathrm{Ca}^{2+}$ signaling and homeostasis are maintained by an intricate array of processes acting in concert (Berridge et al, 2000; Putney et al, 2001) including, for example, inositol trisphosphate $\left(\mathrm{IP}_{3}\right)$ - and ryanodinestimulated release of $\mathrm{Ca}^{2+}$ from endoplasmic reticulum (ER) storage pools (Berridge, 1995; Barritt, 1999; Putney and Ribeiro, 2000), voltage- and ligand-gated ion channel mediated $\mathrm{Ca}^{2+}$ influx (Ghosh and Greenberg, 1995), storeoperated $\mathrm{Ca}^{2+}$ entry (SOCE) (Putney et al, 2001), plasma membrane and sarcoplasmic/ER $\mathrm{Ca}^{2+}$-ATPase pumps (PMCAs and SERCAs) (Brini and Carafoli, 2000), and mitochondrial $\mathrm{Ca}^{2+}$ uptake, storage, and release (Brini and Carafoli, 2000; Fall and Keizer, 2001). Disturbances of intracellular $\mathrm{Ca}^{2+}$ signaling can critically affect cellular function due to calcium's essential role in vital cellular processes including gene expression (Ghosh and Greenberg, 1995), neurogenesis and plasticity (Mattson, 2000), and cell death (Szalai et al, 1999). It is of some interest then that 
lithium acts on several second messenger systems and intracellular signal transducing proteins (Manji et al, 1999; Williams and Harwood, 2000) that are involved in key cellular functions that affect neurogenesis, neuroplasticity, and cell death (Manji et al, 2000).

The notion that intracellular $\mathrm{Ca}^{2+}$ dynamics may be altered in $\mathrm{BD}$ has been suggested by studies using peripheral blood cells as surrogate models, as well as investigations on post-mortem brain. Elevated basal $\left(\left[\mathrm{Ca}^{2+}\right]_{\mathrm{B}}\right)$ and agonist-stimulated $\left(\left[\mathrm{Ca}^{2+}\right]_{\mathrm{S}}\right)$ intracellular $\mathrm{Ca}^{2+}$ levels in the platelets and lymphocytes of bipolar I disorder (BD-I) patients compared with healthy subjects (Dubovsky et al, 1989, 1992; Tan et al, 1990; Plenge et al, 1994; Berk et al, 1995; Emamghoreishi et al, 1997; Hough et $a l, 1999)$ are among the most widely replicated findings in psychobiological studies of BD. Several observations suggest that these abnormalities reflect intrinsic disturbances in cellular function. First, plasma ultrafiltrates from $\mathrm{BD}$ patients did not affect $\left[\mathrm{Ca}^{2+}\right]_{\mathrm{B}}$ in platelets from healthy subjects (Dubovsky et al, 1994). More important, elevated $\left[\mathrm{Ca}^{2+}\right]_{\mathrm{B}}$ (Emamghoreishi et al, 1997) and agonist-stimulated $\left[\mathrm{Ca}^{2+}\right]_{\mathrm{S}}$ (Wasserman et al, 2003) have been reported in B lymphoblast cell lines (BLCLs) from BD patients. Finally, these abnormalities have been observed independent of state of illness (Tan et al, 1990; Kusumi et al, 1994; Emamghoreishi et al, 1997).

Post-mortem brain studies have also revealed changes that may reflect possible 'signatures' of abnormal $\mathrm{Ca}^{2+}$ homeostasis in BD. These include a marked blunting of Gprotein activated phosphoinositide (PI) hydrolysis (Jope et al, 1996) and altered mRNA expression levels of two candidate proteins, which may have important roles in $\mathrm{Ca}^{2+}$ homeostasis, inositol monophosphatase (IMPase) type II (Yoon et al, 2001a), and a transient receptor potential channel, TRPM2 (TRPC7 in earlier nomenclature) (Yoon et al, 2001b), a ligand-gated plasma membrane ion channel which also mediates $\mathrm{Ca}^{2+}$ entry into cells.

Substantial evidence also links lithium treatment to the modulation of intracellular $\mathrm{Ca}^{2+}$ homeostasis. Lithium attenuates agonist-stimulated intracellular $\mathrm{Ca}^{2+}$ responses in a number of cellular paradigms, including astrocytes (Helman et al, 1986), C6 rat glioma cells (Yamaji et al, 1997), rat cerebellar granule cells (Nonaka et al, 1998), GH3 pituitary cells (Varney et al, 1992), rat hippocampal slices (Okamoto et al, 1995), human neutrophils (Forstner et al, 1994), and platelets (Dubovsky et al, 1991). As well, lithium inhibits IMPase uncompetitively (Hallcher and Sherman, 1980), an effect suggested to diminish overactive signaling through PI-linked second messengers and, in turn, $\mathrm{Ca}^{2+}$ (Berridge et al, 1982).

Current understanding of the molecular actions of lithium and other mood stabilizers has been gleaned almost entirely from preclinical work using tissue and cellular models of nonhuman origin, which do not express the disease phenotype. BLCLs from BD patients appear to stably express underlying abnormalities in $\mathrm{Ca}^{2+}$ homeostasis that may be more intimately linked to the pathophysiology of this disorder (Emamghoreishi et al, 1997; Yoon et al, 2001a,b; Wasserman et al, 2003). As such, they afford a particularly pertinent species and disease relevant model in which to explore the mechanisms by which lithium modifies these intracellular $\mathrm{Ca}^{2+}$ disturbances and the relevance of such effects to its therapeutic action. Accordingly, in this study we have exploited this model to determine whether lithium, at a therapeutically relevant concentration, modulates intracellular $\mathrm{Ca}^{2+}$ homeostasis abnormalities identified in BLCLs from BD-I patients, and whether this effect requires chronic exposure. Towards this end, two key components of intracellular $\mathrm{Ca}^{2+}$ mobilization were scrutinized: (1) receptor-G-protein coupled agonist (lysophosphatidic acid (LPA)) stimulation of $\mathrm{Ca}^{2+}$ mobilization through the $\mathrm{PI} / \mathrm{IP}_{3}$ signaling pathway, and (2) SOCE. We report here that chronic ( 7 days), but not acute $(24 \mathrm{~h})$, treatment of BLCLs from both BD-I patients and healthy subjects with lithium, at a therapeutically relevant concentration, significantly elevated $\left[\mathrm{Ca}^{2+}\right]_{\mathrm{B}}$ and attenuated LPAstimulated $\mathrm{Ca}^{2+}$ mobilization and SOCE. These results suggest that the modulation of intracellular $\mathrm{Ca}^{2+}$ homeostasis may be important to the therapeutic action of lithium.

\section{MATERIALS AND METHODS}

\section{Subjects}

BD-1 patients and healthy subjects were recruited and assessed as previously described (Emamghoreishi et al, 1997). Confirmation of diagnoses was performed using the Structured Clinical Interview for DSM-IV Axis I Disorders - Patient Edition (SCID-I/P) (First et al, 1995b) or Nonpatient Edition (SCID-I/NP) (First et al, 1995a) administered by a research psychiatrist or a trained psychiatric assistant. Subjects had no concurrent medical illness, diabetes or hypertension, no recent ( $>3$ months) drug or alcohol abuse (BD-I patients), and were competent to provide informed written consent. Healthy subjects had no family history of psychiatric disorders in first-degree relatives. All subjects were screened with a systems review and a physical examination, where necessary, to rule out the presence of any chronic physical illness. The study was approved by the Human Subjects Review Board of the University of Toronto.

\section{Cell Culture Materials, Reagents, and Drugs}

Characterized fetal bovine serum (FBS) was from HyClone (Logan, UT). RPMI-1640, L-glutamine and trypan blue were obtained from Invitrogen Life Technologies (Burlington, $\mathrm{ON})$. Penicillin $(10000 \mathrm{U} / \mathrm{ml})$, streptomycin $(10 \mathrm{mg} / \mathrm{ml})$, pyruvate, dimethylsulfoxide (DMSO), $\mathrm{MgCl}_{2}, 4$-(2-hydroxyethyl)-1-piperazineethanesulfonic acid (HEPES), LPA (1oleoyl-sn-glycero-3-phosphate), and ethylene glycol bis(2aminoethyl ether)- $N, N, N^{\prime} N^{\prime}$-tetra-acetic acid (EGTA) were from Sigma (Oakville, $\mathrm{ON}$ ). $\mathrm{NaCl}, \mathrm{KCl}, \mathrm{CaCl}_{2}$, and D-glucose were of analytical grade. Polyethylene glycol-8000 was from Mallinckrodt (Point-Claire, QC). Triton X-100 and lithium chloride ( $\mathrm{LiCl}$ ) were from JT Baker (Phillipsburgh, NJ). Thapsigargin (TG) was obtained from Calbiochem (La Jolla, CA) and Fura-2 acetoxymethyl ester (Fura-2 AM) from Molecular Probes (Eugene, OR).

\section{Establishment of BLCLs}

Epstein-Barr virus (EBV) transformed BLCLs were established using standard techniques (Emamghoreishi et al, 1997). The BLCLs for this study were selected from frozen 
stocks established from a cohort of BD-I patients and healthy comparison subjects participating in ongoing studies of signal transduction mechanisms in mood disorders in this laboratory (Emamghoreishi et al, 1997; Yoon et al, 2001a,b). BLCLs were initially expanded in culture for $13-16$ passages in a $95 \%$ air $/ 5 \% \mathrm{CO}_{2}$ humidified incubator at $37^{\circ} \mathrm{C}$ (2-3 days/passage) prior to freezing and storage in the vapor phase of liquid nitrogen.

\section{BLCL Regrowth Conditions}

BLCLs from BD patients and healthy controls were regrown in paired groups from subjects matched on the basis of age and sex. Cells were cultured for $6-10$ passages (4-7 weeks) prior to initiating treatment with $\mathrm{LiCl}$ or vehicle. During regrowth, B cell media (BCM: RPMI 1640, 20\% FBS, 2 mM L-glutamine, $1 \mathrm{mM}$ pyruvate, $100 \mu \mathrm{g} / \mathrm{ml}$ streptomycin, $100 \mathrm{U} / \mathrm{ml}$ penicillin) was replenished every 2 days. Cell counts, and viability, as determined by trypan blue exclusion (Emamghoreishi et al, 1997), were estimated at each feeding.

\section{Drug Treatment Protocol}

Once BLCLs reached the required cell counts $\left(>9 \times 10^{7}\right.$ cells, $>95 \%$ viability), they were divided equally into three groups: two (A and $\mathrm{B}$ ) were fed with aqueous control medium consisting of $\mathrm{BCM}$ to which isotonic $\mathrm{NaCl}$ vehicle solution of the same volume as the lithium solution, $(10 \mathrm{ml} / \mathrm{l}$ $\mathrm{BCM}$ ) was added, while the other $(\mathrm{C})$ was treated with BCM containing $\mathrm{LiCl}$ (final concentration $0.75 \mathrm{mM}$ ). Media was completely replaced by gentle sedimentation $(50 \mathrm{~g}, 10 \mathrm{~min})$ and resuspension of cells every other day for the first 6 days. At day 6, cells were gently sedimented, the supernatant was removed, and the cells were resuspended in RPMI-1640 containing either vehicle solution as above (A) or $0.75 \mathrm{mM}$ $\mathrm{LiCl}$ (B). Cells that had been treated with BCM containing $\mathrm{LiCl}(\mathrm{C})$ for the first 6 days were also washed and taken up in $0.75 \mathrm{mM} \mathrm{LiCl}$ in RPMI-1640. After a further $24 \mathrm{~h}$ incubation, cells were harvested and endpoint $\mathrm{Ca}^{2+}$ mobilization assays were performed.

\section{$\mathrm{Ca}^{2+}$ Mobilization Assays}

Agonist (LPA) stimulation. The assay of LPA-stimulated $\mathrm{Ca}^{2+}$ mobilization was performed as previously described (Rosskopf et al, 1998) with modifications. Briefly, cells (1$3 \times 10^{6} / \mathrm{ml}$ in RPMI-1640) were loaded with Fura-2-AM $(1 \mu \mathrm{M})$ or treated with an equivalent volume of DMSO $(1 \mu \mathrm{l} /$ ml cell suspension; blank sample) as previously described (Emamghoreishi et al, 1997). Following loading, cells were placed on ice until spectrophotofluorometric quantitation to reduce compartmentalization and dye leakage. Immediately prior to analysis, cells were transferred to a spectrophotofluorometric cuvette and allowed to equilibrate in the temperature-controlled chamber of a Perkin-Elmer L50B fluorometer, with gentle stirring for $3 \mathrm{~min}$ at $37^{\circ} \mathrm{C}$. Free- and $\mathrm{Ca}^{2+}$-bound Fura-2 fluorescence intensities (excitation 340/ $380 \mathrm{~nm}$, emission $500 \mathrm{~nm}$ ) were determined as reported elsewhere (Emamghoreishi et al, 1997). After measuring a stable fluorescence ratio $(R)$ for $30 \mathrm{~s}$ to establish a baseline level, a maximally stimulating concentration of LPA
$(100 \mu \mathrm{M}$, determined in preliminary concentrationresponse experiments) was injected directly into the sample as a bolus using a $50 \mu$ l Hamilton syringe. Subsequently, $R$ was measured for an additional $270 \mathrm{~s}$ to determine peak response and initial decay phases of the stimulated $\left[\mathrm{Ca}^{2+}\right]_{i}$ mobilization. Determination of and correction for autofluorescence was performed using the DMSO blank samples processed in parallel (Emamghoreishi et al, 1997). For calibration of Fura-2 fluorescence intensities, equivalent aliquots of cells were lysed with $0.05 \%$ Triton X-100 in a $1 \mathrm{mM} \mathrm{CaCl}_{2}$ medium and $R_{\max }$ was measured. EGTA $(6 \mathrm{mM}$, $30 \mathrm{mM}$ Tris, $\mathrm{pH}$ 8.5) was then added and $R_{\min }$ was measured. $\left[\mathrm{Ca}^{2+}\right]_{\mathrm{i}}$ was then calculated using the Grynkiewicz equation (Grynkiewicz et al, 1985). Determinations were performed on duplicate aliquots of BLCLs from each subject and the mean values were used in all subsequent data analyses.

Thapsigargin stimulation. Determination of $\mathrm{Ca}^{2+}$ leakage from the ER and store depletion-induced SOCE was performed as previously described (Putney and Ribeiro, 2000), with modifications. This technique exploits the effects of TG to deplete TG-sensitive $\mathrm{ER} \mathrm{Ca}^{2+}$ storage pools thereby providing a stimulus for opening of plasma membrane store-operated $\mathrm{Ca}^{2+}$ channels (SOCC) and influx of extracellular $\mathrm{Ca}^{2+}$. Cells $\left(1-3 \times 10^{6} / \mathrm{ml}\right)$ were incubated with Fura-2 AM or DMSO vehicle, after which they were washed, resuspended in nominally $\mathrm{Ca}^{2+}$-free HEPES (HEPES $10 \mathrm{mM}$, glucose $10 \mathrm{mM}, \mathrm{NaCl} 140 \mathrm{mM}, \mathrm{KCl}$ $5 \mathrm{mM}, \mathrm{MgCl}_{2} 1 \mathrm{mM}$ ) buffer and transferred to a spectrophotofluorometric cuvette, equilibrated, and free- and $\mathrm{Ca}^{2+}$-bound Fura-2 fluorescence intensities determined as above. After measuring baseline $R$ for $30 \mathrm{~s}$, a maximally stimulating concentration of TG $(200 \mathrm{nM}$, confirmed in preliminary experiments) was injected as a bolus into the sample. Subsequently, $R$ was measured for an additional $360 \mathrm{~s}$ to ensure depletion of TG-sensitive ER $\mathrm{Ca}^{2+}$ storage pools and to allow $\mathrm{Ca}^{2+}$ levels to recede to a stable secondary baseline. Extracellular $\left[\mathrm{Ca}^{2+}\right]$ was then rapidly raised to physiological concentrations by addition of $\mathrm{CaCl}_{2}$ to a final concentration of $1 \mathrm{mM}$. $R$ was measured for an additional $300 \mathrm{~s}$ to assess the degree of SOCE induced by the $\mathrm{ER} \mathrm{Ca}^{2+}$ depletion stimulus. Correction for autofluorescence and calibration of Fura-2 fluorescence intensities were performed using equivalent aliquots of cells and $\left[\mathrm{Ca}^{2+}\right]_{i}$ calculated as above. Determinations were performed on duplicate aliquots of BLCLs as above and the mean values were used in all subsequent data analyses.

\section{Statistics}

Data are presented as means \pm standard error of the mean (SEM). Differences in the proportion of males to females in each diagnostic group were analyzed by a $\chi^{2}$ test. After confirming homogeneity of variance (Levine's test), differences in dependent variables between subject groups were analyzed by repeated measures multivariate analysis of variance (MANOVA) with diagnostic group and drug treatment as factors. Subsequent repeated measures univariate analyses (ANOVA) were used to determine the differences in specific dependent variables. Dependent measures determined in the LPA-stimulated $\mathrm{Ca}^{2+}$ 
mobilization paradigm were analyzed separately from those of the TG-stimulation protocol. This was done to avoid the reduced power of a single MANOVA, using all dependent cellular measures, resulting from exclusion of records with missing values: the cumulative loss of samples due to procedural difficulties resulted in a number of missing values among each set of experimental parameters. Differences between acute and chronic lithium treatment were analyzed by repeated measures ANOVA followed by simple contrasts to distinguish effects of time of exposure compared with vehicle control. Potential effects of other factors, including mood state and type of mood stabilizer treatment at the time of study, familial history of mood disorders, and psychiatric comorbidities, were assessed statistically using repeated measures ANOVA with the demographic characteristic as the between-subject factor, followed by Tukey's HSD test for post hoc comparisons. Statistical differences with two-tailed probability values of $p<0.05$ were taken as significant. Statistical analyses were performed using the SPSS (version 9.5, Chicago, IL) statistical package.

\section{RESULTS}

\section{Subjects}

Table 1 summarizes the demographic characteristics of the BD-I patients and healthy comparison subjects from whom BLCLs were used in this study. While BLCL samples were regrown from $26 \mathrm{BD}-\mathrm{I}$ patients and 16 healthy subjects, the actual numbers of subject samples analyzed for each parameter were less due to methodological difficulties resulting in sample loss during one or the other of the assay protocols used. Patient and healthy subject groups did not differ statistically in proportion of females to males $\left(\chi^{2}=1.27, p=0.26\right)$ or in mean age $(t=0.994, p=0.33)$.

\section{Effect of Chronic Lithium Treatment on Agonist- Stimulated Intracellular $\mathrm{Ca}^{2+}$ Mobilization}

Figure 1a depicts a representative response to LPA stimulation in BLCLs incubated for 7 days with $0.75 \mathrm{mM}$ $\mathrm{LiCl}$ or vehicle. LPA evoked a rapid rise in $\left[\mathrm{Ca}^{2+}\right]_{\mathrm{i}}$ from $\left[\mathrm{Ca}^{2+}\right]_{\mathrm{B}}$ reaching a peak response (peak $\left[\mathrm{Ca}^{2+}\right]_{\mathrm{S}}$ ) between 20 and $100 \mathrm{~s}$ after stimulation, following which it declined towards baseline levels. The decay phase reflects the restitution of $\mathrm{Ca}^{2+}$ towards baseline levels through homeostatic control mechanisms including plasma membrane and ER $\mathrm{Ca}^{2+}$ ATPase pumps (Brini and Carafoli, 2000) and $\mathrm{Na}^{+} / \mathrm{Ca}^{2+}$ exchangers (Blaustein and Lederer, 1999). The parameters examined for lithium modulation in this paradigm included the $\left[\mathrm{Ca}^{2+}\right]_{B}$, peak $\left[\mathrm{Ca}^{2+}\right]_{S}$, the absolute difference $\left(\Delta\left[\mathrm{Ca}^{2+}\right]_{\mathrm{S}}\right)$ between $\left[\mathrm{Ca}^{2+}\right]_{S}$ and $\left[\mathrm{Ca}^{2+}\right]_{\mathrm{B}}$, and the slope of the initial rate of rise in LPAstimulated $\left[\mathrm{Ca}^{2+}\right]_{S}\left(d\left[\mathrm{Ca}^{2+}\right]_{S} / d t\right)$.

The effect of chronic lithium treatment on the above parameters of $\mathrm{Ca}^{2+}$ mobilization in BLCLs from patients and healthy comparison subjects is presented in Figures 1a and 2. MANOVA revealed significant main effects of lithium treatment $(\mathrm{F}=7.18 ; \mathrm{df}=3,31 ; p=0.001)$ and diagnosis $(\mathrm{F}=3.42 ; \quad \mathrm{df}=3,31 ; \quad p=0.03), \quad$ but no interaction $(\mathrm{F}=0.243 ; \mathrm{df}=3,31 ; p=0.87)$ between these factors. Sub-
Table I Demographic Characteristics

\begin{tabular}{lcc}
\hline & $\begin{array}{l}\text { Bipolar I } \\
\text { patients }\end{array}$ & $\begin{array}{l}\text { Healthy } \\
\text { controls }\end{array}$ \\
\hline Total & 26 & 17 \\
Sex(M/F) & $16 / 10$ & $7 / 10$ \\
Age (years) & $42.2 \pm 2.3^{\mathrm{a}}$ & $39.5 \pm 2.8$ \\
Age at onset of Illness & $27.0 \pm 2.7$ years & $\mathrm{N} / \mathrm{A}$
\end{tabular}

State at time of venipuncture (n)

Euthymic

15

Depressed

N/A

Hypomanic

Manic

3

2

Cotmorbidites (n) ${ }^{\mathrm{b}}$

Alcohol abuse/depedence

Compulsive disorders

N/A

Eating disorders

Panic disorder

Family History of Mood Disorders

$(n)^{c}$

Positive

Negative

Unknown

N/A

8

Mood stabilizer medication time of

study (n)

Lithium

Valproate

Carbamazepine

Combination $^{d}$

None

N/A

Other Psychotropic medications at

time of study (n)

SSRIS

Neuroleptics

Anxiolytics

None

N/A

a Data presented as mean \pm SEM. N/A indicates not applicable.

'These categories are nonexclusive; an individual may meet more than one comorbid diagnosis.

${ }^{\mathrm{C}}$ Familial mood disorders include bipolar disorder, major depressive disorder dysthymia, seasonal affective disorder, and schizaoaffective disorder (bipolar type).

${ }^{d}$ Combination thearapy refers to lithium plus valproate or carbamazepine.

sequent univariate ANOVAs revealed significant effects of lithium treatment on $\left[\mathrm{Ca}^{2+}\right]_{\mathrm{B}} \quad(\mathrm{F}=8.47 ; \quad \mathrm{df}=1,33$; $p=0.006)$, peak $\left[\mathrm{Ca}^{2+}\right]_{\mathrm{S}}(\mathrm{F}=9.94 ; \mathrm{df}=1,33 ; p=0.003)$, and $\Delta\left[\mathrm{Ca}^{2+}\right]_{\mathrm{s}}(\mathrm{F}=11.1 ; \mathrm{df}=1,33 ; p=0.002)$, but not $d\left[\mathrm{Ca}^{2+}\right]_{S} / d t \quad(\mathrm{~F}=1.54 ; \mathrm{df}=1,33 ; p=0.224)$ in the LPAstimulation protocol. While exposure of BLCLs to lithium for 7 days resulted in a modest but significant elevation in $\left[\mathrm{Ca}^{2+}\right]_{\mathrm{B}}$ in both the patient $(11.1 \%)$ and the healthy subject 

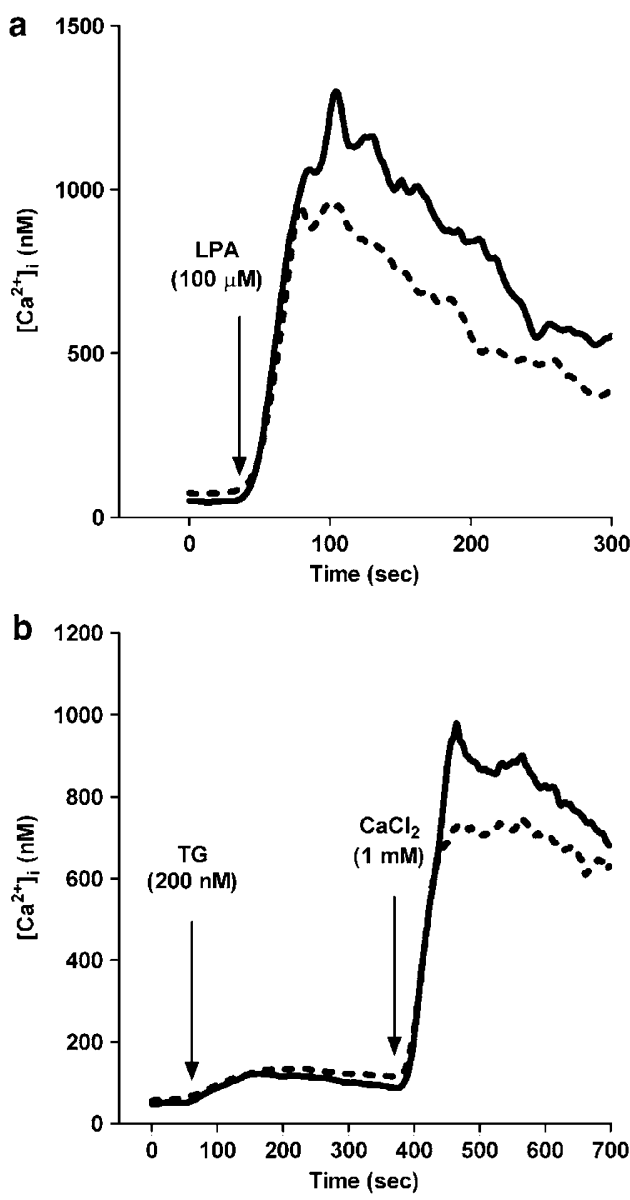

Figure I Effect of Chronic Lithium Treatment on Agonist-Stimulated $\mathrm{Ca}^{2+}$ Mobilization and ER Store-Depletion-Induced $\mathrm{Ca}^{2+}$ Entry in BLCLs. Cells were pretreated for 7 days with $\mathrm{LiCl}(0.75 \mathrm{mM})$ or vehicle. Cytosolic $\mathrm{Ca}^{2+}$ levels $\left(\left[\mathrm{Ca}^{2+}\right]_{i}\right)$ were measured using the $\mathrm{Ca}^{2+}$-indicator Fura 2-AM as described in the Materials and methods. (a) Typical $\mathrm{Ca}^{2+}$ responses induced by $100 \mu \mathrm{M}$ LPA in control (solid line) vs lithium-treated (broken line) cells from a healthy subject are shown. The arrow indicates the time of LPA administration. (b) Representative $\mathrm{Ca}^{2+}$ responses after the addition of $200 \mathrm{nM} \mathrm{TG}$ in $\mathrm{Ca}^{2+}$-free medium, followed by the reintroduction of I mM extracellular $\mathrm{Ca}^{2+}$ in control (solid line) vs lithium-treated (broken line) BLCLs from a healthy subject is shown. Arrows indicate the time of TG/extracellular $\mathrm{Ca}^{2+}$ administration.

$(10.0 \%)$ groups, the same treatment caused a significant attenuation in both $\left[\mathrm{Ca}^{2+}\right]_{\mathrm{S}}(12.2 \%$ lower in patients, $11.1 \%$ lower in healthy subjects) and $\Delta\left[\mathrm{Ca}^{2+}\right]_{\mathrm{S}}(14.1 \%$ lower in patients, $12.3 \%$ lower in healthy subjects) compared to vehicle treatment. The $d\left[\mathrm{Ca}^{2+}\right]_{\mathrm{s}} / d t$ was also reduced in lithium-treated samples $(11.5 \%)$ but the difference was not statistically significant.

To test whether the above lithium-induced changes were dependent on the duration of exposure, BLCLs from a subset of subjects (eight patients, two healthy) were treated for $24 \mathrm{~h}$ or 7 days with $0.75 \mathrm{mM}$ lithium or vehicle, and LPAstimulated $\mathrm{Ca}^{2+}$ responses determined. As shown in Figure $4 \mathrm{a}$ and $\mathrm{b}$, acute lithium treatment did not significantly influence $\left[\mathrm{Ca}^{2+}\right]_{\mathrm{B}}$ and peak $\left[\mathrm{Ca}^{2+}\right]_{\mathrm{S}}$ in BLCLs (simple contrasts: $\mathrm{F}=1.73 ; \mathrm{df}=1,9 ; p=0.22$ and $\mathrm{F}=1.55 ; \mathrm{df}=1,9$; $p=0.245$, respectively) in contrast to the chronic lithium treatment paradigm $(\mathrm{F}=4.28 ; \mathrm{df}=1,9 ; \quad p=0.068$ and $\mathrm{F}=21.0 ; \mathrm{df}=1,9 ; p=0.001$, respectively).
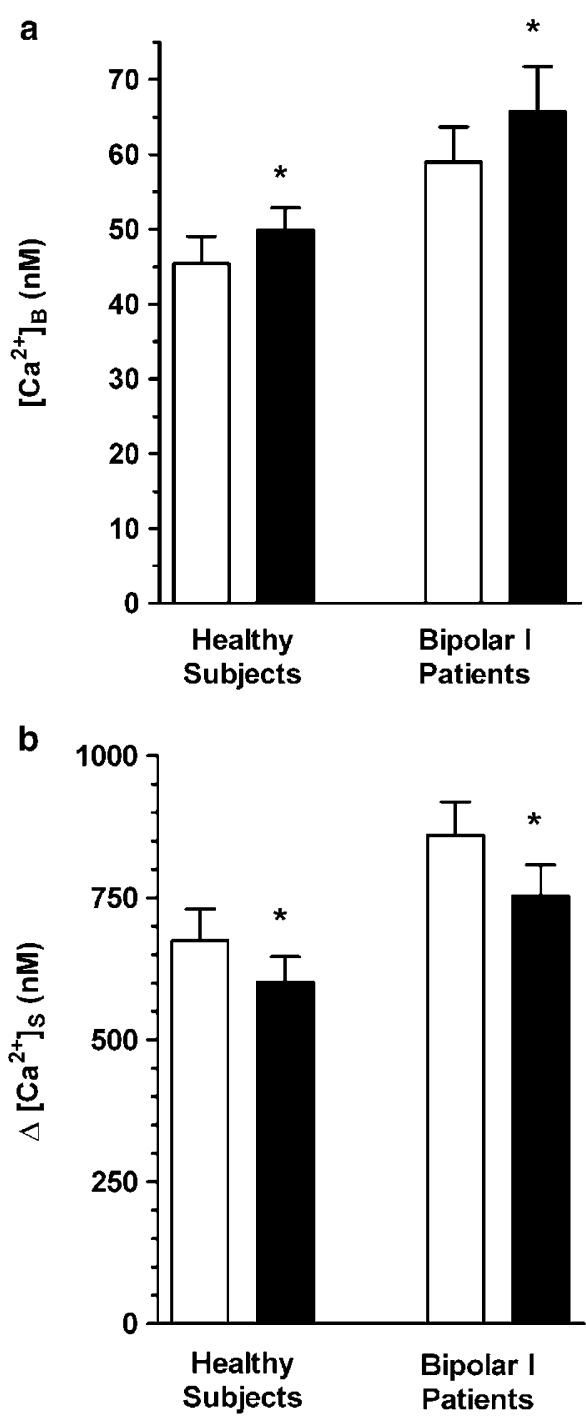

Figure 2 Effect of Chronic Lithium Treatment on Parameters of LPAStimulated Intracellular Calcium Mobilization. Cells were incubated for 7 days with $\mathrm{LiCl}(0.75 \mathrm{mM})$ or vehicle. The $\left[\mathrm{Ca}^{2+}\right]$ i was monitored prior to and following stimulation with $100 \mu \mathrm{M}$ LPA as described in Figure Ia. Chronic lithium treatment increased basal intracellular $\mathrm{Ca}^{2+}$ levels $\left(\left[\mathrm{Ca}^{2+}\right]_{B}\right)$ (a) and attenuated the absolute difference between $\left[\mathrm{Ca}^{2+}\right]_{S}$ and $\left[\mathrm{Ca}^{2+}\right]_{\mathrm{B}}\left(\Delta\left[\mathrm{Ca}^{2+}\right]_{\mathrm{S}}\right)(\mathrm{b})$ in response to LPA stimulation in BLCLs from both healthy subjects and BD-I patients. The open bars $(\square)$ represent vehicle-treated BLCLs, while the solid bars $(\mathbf{\square})$ represent BLCLs treated chronically with lithium. Values represent the mean and SEM of determinations made in 15 healthy subjects and 20 BD-I patients. *p $<0.05$ compared to vehicle-treated BLCLs (ANOVA with Tukey's post hoc tests).

Effect of Chronic Lithium Treatment on ThapsigarginSensitive ER $\mathrm{Ca}^{2+}$ Release and Parameters of SOCE

Figure $1 \mathrm{~b}$ demonstrates the time course of TG-induced depletion of intracellular $\mathrm{Ca}^{2+}$ stores and subsequent store depletion-stimulated influx of extracellular $\mathrm{Ca}^{2+}$ in BLCLs incubated for 7 days with $0.75 \mathrm{mM}$ lithium or vehicle. In a $\mathrm{Ca}^{2+}$-free medium, the addition of TG $(200 \mathrm{nM})$ caused a slow increase in BLCL $\left[\mathrm{Ca}^{2+}\right]_{\mathrm{i}}$ to a new baseline $\left(\left[\mathrm{Ca}^{2+}\right]_{\mathrm{B} 2}\right)$. Subsequent addition of $\mathrm{Ca}^{2+}(1 \mathrm{mM})$ resulted in a rapid rise of $\left[\mathrm{Ca}^{2+}\right]_{\mathrm{i}}$ confirming the well-known observation obtained in other cell types that sustained $\mathrm{Ca}^{2+}$ entry is linked to 
store depletion induced by TG (Putney et al, 2001). Parameters measured to characterize the TG-induced SOCE response include the $\left[\mathrm{Ca}^{2+}\right]_{\mathrm{B}}$, peak TG-sensitive $\left[\mathrm{Ca}^{2+}\right]_{\mathrm{i}}$ accumulation $\left(\left[\mathrm{Ca}^{2+}\right]_{\mathrm{TG}}\right)$, the baseline plateau before reintroduction of $\mathrm{Ca}^{2+}$ to the external medium $\left(\left[\mathrm{Ca}^{2+}\right]_{\mathrm{B} 2}\right.$, the peak of $\mathrm{Ca}^{2+}$ influx $\left(\left[\mathrm{Ca}^{2+}\right]_{\text {influx }}\right)$, the difference between
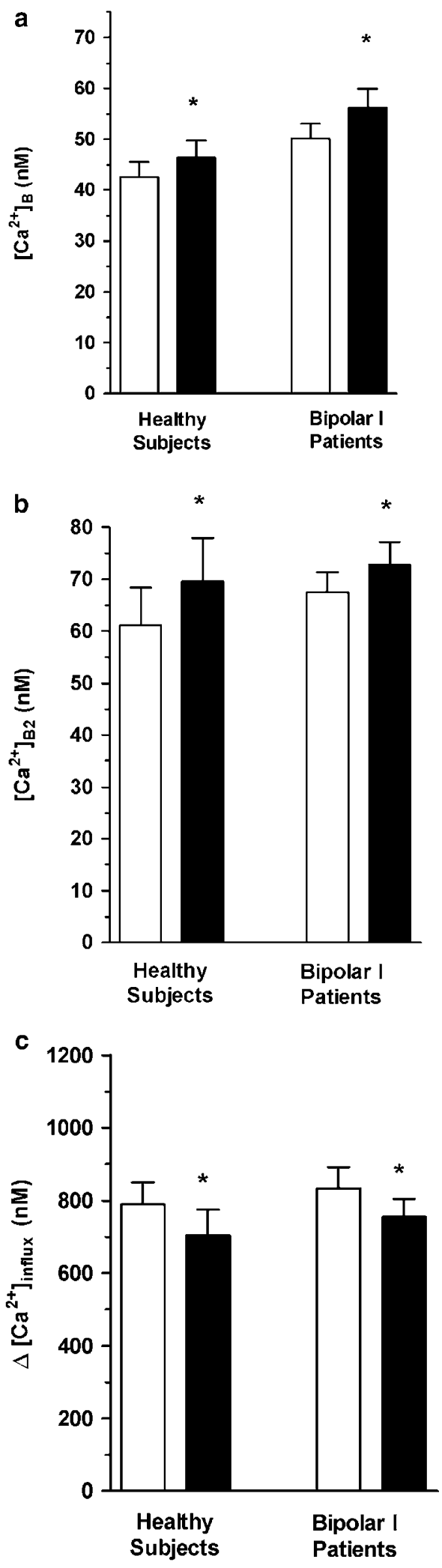

$\left[\mathrm{Ca}^{2+}\right]_{\text {influx }}$ and $\left[\mathrm{Ca}^{2+}\right]_{\mathrm{B} 2}\left(\Delta\left[\mathrm{Ca}^{2+}\right]_{\text {influx }}\right)$, and the slope of the initial phase of rise in $\left[\mathrm{Ca}^{2+}\right]_{\text {influx }}\left(d\left[\mathrm{Ca}^{2+}\right]_{\text {influx }} / d t\right)$.

The effects of chronic lithium treatment on the parameters of the 'TG-Ca ${ }^{2+}$ add back protocol' in BLCLs from the $\mathrm{BD}$ patients and healthy comparison subjects are presented in Figures $1 \mathrm{~b}$ and 3 . Repeated measures MANOVA of these parameters revealed a significant effect of lithium treatment $(\mathrm{F}=8.36 ; \mathrm{df}=5,30 ; p=0.00005)$ but not diagnosis $(\mathrm{F}=1.28 ; \quad \mathrm{df}=5,30 ; p=0.30)$, and no significant interaction $(\mathrm{F}=0.551 ; \mathrm{df}=5,30 ; p=0.74)$ between these two factors. Subsequent univariate ANOVAs revealed significant effects of chronic lithium treatment on $\left[\mathrm{Ca}^{2+}\right]_{\mathrm{B}} \quad(\mathrm{F}=9.42 ; \quad \mathrm{df}=1,34 ; \quad p=0.004), \quad\left[\mathrm{Ca}^{2+}\right]_{\mathrm{B} 2}$ $(\mathrm{F}=10.1 ; \quad \mathrm{df}=1,34 ; \quad p=0.003), \quad\left[\mathrm{Ca}^{2+}\right]_{\text {influx }} \quad(\mathrm{F}=8.36 ;$ $\mathrm{df}=1,34 ; p=0.007)$, and $\Delta\left[\mathrm{Ca}^{2+}\right]_{\text {influx }}(\mathrm{F}=11.7 ; \mathrm{df}=1,34 ;$ $p=0.002)$, but not $\left[\mathrm{Ca}^{2+}\right]_{\mathrm{TG}}(\mathrm{F}=1.22 ; \mathrm{df}=1,34 ; p=0.278)$ or $d\left[\mathrm{Ca}^{2+}\right]_{\text {influx }} d t \quad(\mathrm{~F}=2.49 ; \quad \mathrm{df}=1,34 ; \quad p=0.124)$, in TG-stimulated BLCLs. $\left[\mathrm{Ca}^{2+}\right]_{\mathrm{B}}$ and $\left[\mathrm{Ca}^{2+}\right]_{\mathrm{B} 2}$ were significantly higher in BLCLs treated with lithium compared with vehicle control in both the patient $(12.0$ and $8.8 \%$, respectively) and healthy subjects ( 7.0 and $13.3 \%$, respectively). As well, chronic lithium treatment modestly, but significantly, attenuated both $\left[\mathrm{Ca}^{2+}\right]_{\text {influx }}(9.0 \%$ in BD-I, $7.9 \%$ in healthy subjects) as well as $\Delta\left[\mathrm{Ca}^{2+}\right]_{\text {influx }}(10.6 \%$ lower in BD-I, 10.4\% lower in healthy subjects). As with LPA-stimulated $\mathrm{Ca}^{2+}$ mobilization, there was no difference in $\left[\mathrm{Ca}^{2+}\right]_{\mathrm{B}}$ between vehicle and acute lithium-treated samples $(\mathrm{F}=1.45 ; \mathrm{df}=1,13 ; p=0.25$; Figure $4 \mathrm{c})$, whereas the difference between vehicle and chronically treated samples was statistically significant $(\mathrm{F}=4.36 ; \mathrm{df}=1,9$; $p=0.05)$. Similarly, while $\left[\mathrm{Ca}^{2+}\right]_{\mathrm{B} 2}$ in BLCLs treated for $24 \mathrm{~h}$ with lithium were not significantly reduced $(\mathrm{F}=3.15$; $\mathrm{df}=1,13 ; p=0.10)$, those treated for 7 days demonstrated higher $\left[\mathrm{Ca}^{2+}\right]_{\mathrm{B} 2}$ compared with vehicle $(12.5 \%, \mathrm{~F}=8.65$; $\mathrm{df}=1,13 ; \quad p=0.01 ;$ data not shown). Finally, while $\left[\mathrm{Ca}^{2+}\right]_{\text {influx }}$ did not differ between vehicle and acute lithium treatment conditions $(\mathrm{F}=1.39 ; \quad \mathrm{df}=1,13 ; \quad p=0.26$; Figure 4d), it was in fact reduced in chronic lithium-treated BLCLs compared with the vehicle-treated condition $(\mathrm{F}=5.17 ; \mathrm{df}=1,13 ; p=0.04)$.

\section{Relationship Between Calcium Mobilization Parameters and Bipolar Patient Characteristics}

Other than the observation of significantly higher $\left[\mathrm{Ca}^{2+}\right]_{\mathrm{B}}$ in BLCLs from bipolar patients on lithium monotherapy at the time of the study compared with healthy subjects $(\mathrm{F}=3.11 ; \mathrm{df}=3,24 ; p=0.04)$ there were no statistically

\footnotetext{
Figure 3 Effect of Chronic Lithium Treatment on Parameters of Thapsigargin-Induced Store Depletion and Store-Operated $\mathrm{Ca}^{2+}$ Entry. Cells were incubated for 7 days with $\mathrm{LiCl}(0.75 \mathrm{mM})$ or vehicle. Storeoperated $\mathrm{Ca}^{2+}$ entry was monitored using the 'TG-Ca ${ }^{2+}$ add back' protocol as described in Figure Ib. Chronic lithium exposure increased the basal intracellular $\mathrm{Ca}^{2+}$ levels prior to $\left(\left[\mathrm{Ca}^{2+}\right]_{\mathrm{B}}\right)$ (a) and following $\mathrm{TG}$ challenge $\left(\left[\mathrm{Ca}^{2+}\right]_{\mathrm{B} 2}\right)$ (b) and attenuated the absolute difference between $\left[\mathrm{Ca}^{2+}\right]_{\text {influx }}$ and $\left[\mathrm{Ca}^{2+}\right]_{\mathrm{B} 2}\left(\Delta\left[\mathrm{Ca}^{2+}\right]_{\text {influx }}\right)$ (c) in response to the readdition of extracellular $\mathrm{Ca}^{2+}$, in BLCLs from both healthy subjects and BD-I patients. Open bars $(\square)$ represent vehicle-treated BLCLs, while solid bars (a) represent BLCLs treated chronically with lithium. Values represent the mean and SEM of determinations made in 13 healthy subjects and 24 BDpatients. $*$ $p<0.05$ compared to vehicle-treated BLCLs (ANOVA with Tukey's post hoc tests).
} 
LPA-Stimulated $\mathrm{Ca}^{2+}$ Mobilization
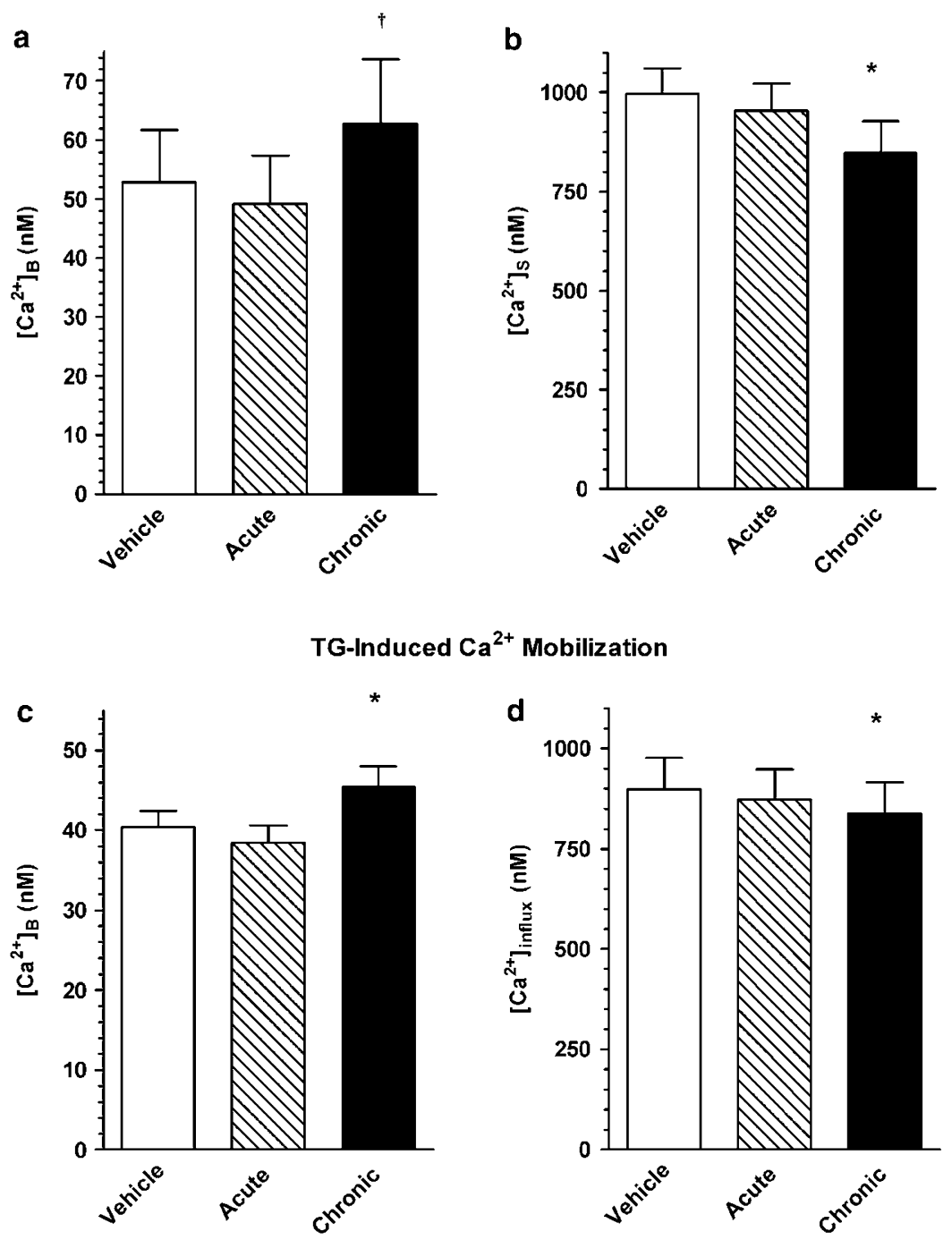

Figure 4 Effect of Acute vs Chronic Lithium Treatment on Basal $\mathrm{Ca}^{2+}$ levels, LPA-stimulated Ca ${ }^{2+}$ Mobilization, and Thapsigargin-Induced StoreOperated $\mathrm{Ca}^{2+}$ Entry. BLCLs were treated with vehicle (open bars) or with $\mathrm{LiCl}(0.75 \mathrm{mM}$ ) for $24 \mathrm{~h}$ (hatched bars) or 7 days (closed bars $\mathbf{0}$ ). Cells loaded with Fura-2 were challenged with LPA (a, b) or TG-induced SOCC (c, d) as described in Figure I. Values represent the mean and SEM of determinations made in two healthy subjects and eight BD-I patients ( $a, b)$ or five healthy and I 0 BD-I patients (c, d). $* 0<0.05$ and ${ }^{\dagger} p=0.068$ compared to vehicle-treated BLCLs (repeated measures ANOVA with simple contrasts).

significant differences found in the LPA- and TG-induced $\mathrm{Ca}^{2+}$ mobilization indices measured within the patient group stratified on factors of mood state of illness at time of study (healthy subjects, and euthymic, depressed, and hypomanic/manic bipolar patients, $\quad F$ 's $=0.06-1.69$; $\mathrm{df}=3,26$; $p$ 's $>0.2$ ), psychiatric comorbidity (healthy subjects and bipolar patients with no comorbidity, alcohol abuse/dependence, or other comorbidity, F's $=0.41-1.63$; $\mathrm{df}=3,26 ; p$ 's $>0.21)$ and family history of mood disorders (healthy subjects, positive, negative, or unknown, F's $=0.26-2.56 ; \mathrm{df}=3,26 ; p^{\prime} \mathrm{s} \geqslant 0.08$ ) (data not shown).

\section{DISCUSSION}

The principal findings of this study are that chronic, but not acute, treatment of BLCLs from both BD-I patients and healthy subjects with a therapeutically relevant concentra- tion of lithium significantly attenuated LPA-stimulated $\mathrm{Ca}^{2+}$ responses (a G-protein-coupled receptor activated signaling pathway), and TG-evoked store-depletion-induced $\mathrm{Ca}^{2+}$ influx (a measure of SOCE). At the same time, $\left[\mathrm{Ca}^{2+}\right]_{\mathrm{B}}$ was significantly elevated by chronic, but not acute, lithium treatment. Taken together, these findings support the notion that lithium alters key processes regulating intracellular $\mathrm{Ca}^{2+}$ homeostasis, effects which may be particularly relevant to understanding the molecular and cellular actions responsible for its therapeutic effects.

As the pharmacological agents used to probe intracellular $\mathrm{Ca}^{2+}$ homeostatic control in this study act on cascades of interacting proteins and second messengers, the loci at which lithium acts to produce the observed effects can only be surmised in broad terms. It is unlikely, however, that the attenuating effects of lithium are related to factors that modify the rate of $\mathrm{Ca}^{2+}$ mobilization following agonist stimulation or the rate of $\mathrm{Ca}^{2+}$ influx induced by store 
depletion as these changes occurred without statistically significant differences in $d\left[\mathrm{Ca}^{2+}\right]_{\mathrm{S}} / d t$ and $\mathrm{d}\left[\mathrm{Ca}^{2+}\right]_{\text {influx }} / \mathrm{d} t$, the initial rates of activation of these responses. Furthermore, they do not appear to be related to an effect of lithium to reduce the size of the TG-sensitive ER stores, since neither acute nor chronic lithium treatment had any significant effect on $\left[\mathrm{Ca}^{2+}\right]_{\mathrm{TG}}$.

As SOCE may contribute to the net $\mathrm{Ca}^{2+}$ entry in the LPA (Warsh et al, unpublished data) as well as in the TGstimulation paradigms (Putney et al, 2001), an effect of lithium on mechanisms regulating SOCE could be expected to attenuate both responses. As TG induces store depletion through an $\mathrm{IP}_{3}$ receptor $\left(\mathrm{IP}_{3} \mathrm{R}\right)$-independent mechanism, the effect of lithium on this SOCE component is likely to be related to actions distinct from its well-established modulatory effect on PI signaling (Hallcher and Sherman, 1980; Berridge et al, 1982). The SOCE apparatus is complex, involving the orchestrated action of SOCC, $\mathrm{IP}_{3} \mathrm{Rs}$, and SERCAs (Barritt, 1999; Putney et al, 2001). Functional interactions between mitochondria and ER can also influence $\mathrm{Ca}^{2+}$ mobilization through SOCE (Fall and Keizer, 2001). While knowledge is sparse on the effects of lithium on these families of membrane proteins, the observed increase in $\left[\mathrm{Ca}^{2+}\right]_{\mathrm{B}}$ would not be expected if the attenuating effect of lithium on the stimulated $\mathrm{Ca}^{2+}$ mobilization were due to upregulation of the levels and/or function of PMCAs or SERCAs. Similarly, the lack of differences in $\left[\mathrm{Ca}^{2+}\right]_{\mathrm{TG}}$ argues against an effect of lithium on the functional activity of the SERCAs.

The potential involvement of TRPM2 or other members of the family of TRP proteins in the effect of lithium to attenuate LPA- and TG-stimulated $\mathrm{Ca}^{2+}$ mobilization also merits consideration. TRPM2 mRNA levels were significantly reduced in BLCLs from BD patients showing elevated BLCL $\left[\mathrm{Ca}^{2+}\right]_{\mathrm{B}}$ and varied inversely with $\left[\mathrm{Ca}^{2+}\right]_{\mathrm{B}}$ (Yoon et al, 2001b). Furthermore, in preliminary experiments, sustained elevation of BLCL $\left[\mathrm{Ca}^{2+}\right]_{\mathrm{i}}$ by ionomycin treatment suppressed TRPM2 mRNA levels (Yoon, 2002). While chronic lithium treatment suppresses TRPC3 protein levels in BLCLs from BD patients (Andreopoulos et al, 2003), the extent to which protein and mRNA levels of TRPM2 and other TRP proteins expressed in BLCLs are also downregulated and the relationship of any such changes to the altered functional indices demonstrated in this work remain to be elaborated.

It is also possible that the effect of chronic lithium treatment to attenuate LPA-stimulated $\mathrm{Ca}^{2+}$ mobilization is mediated through a process distinct from that which affects the TG-evoked SOCE response. In addition to inhibiting IMPase (Hallcher and Sherman, 1980), lithium could attenuate LPA-stimulated $\mathrm{Ca}^{2+}$ mobilization by inhibiting $\mathrm{G}_{\beta \gamma}$-mediated responses. Chronic lithium administration has been demonstrated to interfere with the dissociation of $G_{i}$ into its active components, thereby removing the tonic inhibitory influence on adenylyl cyclase and diminishing signal transduction through the $\mathrm{PI} / \mathrm{IP}_{3}$ system (Masana et al, 1992; Wang and Friedman, 1999). Chronic lithium treatment has also been shown to reduce receptor G-protein coupling (Wang and Friedman, 1999) and decrease both receptor- and postreceptor-stimulated PI hydrolysis (reviewed in Hudson et al, 1993; Jope and Williams, 1994).
The extent to which the modulatory effect of lithium on intracellular $\mathrm{Ca}^{2+}$ mobilization in the current cellular paradigm represents a primary effect on one or more of the elements in the $\mathrm{PI} / \mathrm{Ca}^{2+}$ signaling system, as opposed to a secondary one mediated through cross-talk mechanisms also merits consideration. For example, cAMP-mediated signaling promotes the inhibition of $\mathrm{Ca}^{2+}$ influx (Rasmussen, 1986), modulates $\mathrm{IP}_{3} \mathrm{Rs}$ (Supattapone et al, 1988; Patel et al, 1999), and enhances the removal of $\mathrm{Ca}^{2+}$ from the cytosol by promoting the action of PMCA pumps (Helman et al, 1986). As well, protein kinase A (PKA) can modulate the $\mathrm{PI} / \mathrm{Ca}^{2+}$ signaling system through the phosphorylation of several intracellular targets including receptors, G proteins, PI kinase, and phospholipase C (Supattapone et al, 1988; Hajnoczky et al, 1993; Galas and Harden, 1997). Abnormalities of the cAMP-PKA signaling cascade have also been implicated in the pathophysiology of $\mathrm{BD}$ and as a target of lithium action (Perez et al, 2000; Chang et al, 2002). Furthermore, the cAMP system is, in turn, subject to cross-regulation by $\mathrm{Ca}^{2+}$ signaling through regulation at a variety of points in the cAMP signaling cascade (Choi et al, 1993; Cooper et al, 1995). Thus, it may be that multiple actions of lithium on diverse signal transduction systems are essential to its therapeutic efficacy in BD.

While the decrements in LPA-stimulated $\mathrm{Ca}^{2+}$ mobilization and TG-induced $\mathrm{Ca}^{2+}$ influx caused by chronic lithium treatment were modest, the true magnitude of the attenuating effects may have been underestimated. Fura-2, which has a $K_{\mathrm{d}}$ for $\mathrm{Ca}^{2+}$ in the order of $224 \mathrm{nM}$ (at $37^{\circ} \mathrm{C}$ ) (Nuccitelli, 1994), becomes increasingly saturated at high $\left[\mathrm{Ca}^{2+}\right]_{\mathrm{i}}$, such as attained with the LPA and TG protocols used in this study. Thus, at such high $\mathrm{Ca}^{2+}$ concentrations (eg 700-1000 nM), Fura-2 would be relatively less sensitive to changes in $\left[\mathrm{Ca}^{2+}\right]_{\mathrm{i}}$ providing only an approximation of the true magnitude of the $\mathrm{Ca}^{2+}$ changes. Although higher affinity fluorescence $\mathrm{Ca}^{2+}$ chelating dyes are available (Nuccitelli, 1994), their use would have been at the expense of accurately estimating the $\left[\mathrm{Ca}^{2}{ }^{+}\right]_{\mathrm{B}}$. Second, because the $\mathrm{Ca}^{2+}$ assay employed gives a 'static' measure, averaged across the entire population of cells in the light beam path of the fluorometer, it does not provide a dynamic picture of the effects that may occur in subpopulations of responding cells in which differences may be more pronounced. Finally, differences observed in this study may also have been affected by phenotypic heterogeneity of the BD patient population studied, a known confounding factor in genetic and molecular investigations of BD (Goodwin and Jamison, 1990; Lenox et al, 2002).

The attenuating effects of lithium on LPA- and TGinduced $\mathrm{Ca}^{2+}$ mobilization were only evident after 7 days but not $24 \mathrm{~h}$ of exposure suggesting that these effects are a result of chronic exposure to lithium. This duration of treatment, which has been widely used in studies of mood stabilizer actions in cell lines (Varney et al, 1992; Ozaki and Chuang, 1997; Yamaji et al, 1997; Nonaka et al, 1998; Wang et al, 2001), is one through which drug exposure can be managed without inducing significant cellular toxicity (BLCL viability after 7 days exposure $>95 \%$ ). While this time interval is still shorter than that required for full clinical response to lithium, antimanic effects of lithium are evident at as early as 1 week of treatment (Schou, 1968). Also, unlike the clinical situation, in which pharmacokinetic 
factors contribute, in part, to latency of onset of action, cells studied in the ex vivo paradigm here are directly and immediately exposed to a constant therapeutic concentration of lithium, thus presumably expediting the onset of biochemical actions. Finally, the lithium concentration used in this study $(0.75 \mathrm{mM})$ falls in the mid-therapeutic range of serum concentrations $(0.5-1.0 \mathrm{mM})$ used to guide lithium dosing clinically (Gelenberg et al, 1989) and within the range of those achieved in brain during therapeutic dosing (Kato et al, 1993; Plenge et al, 1994). However, the use of a single lithium concentration in this study precludes conclusions regarding whether the observed effects of lithium on parameters of $\mathrm{Ca}^{2+}$ mobilization were dosedependent or maximal.

The lack of a differential effect of lithium on the $\mathrm{Ca}^{2+}$ mobilization in BLCLs from BD patients as compared with those from healthy subjects also merits consideration as it might question the therapeutic implications of lithiuminduced $\mathrm{Ca}^{2+}$ mobilization changes observed. However, this could be related to several factors, including insensitivity to detect a small effect in a relatively small subject sample population, the limited sensitivity of the $\mathrm{Ca}^{2+}$ indicator used at high $\left[\mathrm{Ca}^{2+}\right]_{S}$, as noted above, and the relatively large variance in the assay of LPA-stimulated $\mathrm{Ca}^{2+}$ mobilization. While the duration of exposure to lithium is sufficient to demonstrate certain chronic effects, as argued above, it may still be too short to capture cellular and molecular changes that evolve more slowly, in perhaps a diagnosis-specific fashion.

The alterations seen following chronic lithium treatment in this nonexcitable cell paradigm likely represent only one of a sequence of changes that, in neurons, act in conjunction to 'correct' disturbed $\mathrm{Ca}^{2+}$ homeostasis. In this regard, chronic lithium treatment also inhibits NMDA receptorinduced $\mathrm{Ca}^{2+}$ influx possibly by decreasing NR2B tyrosine phosphorylation (Hashimoto et al, 2002), effects that may underlie its protective actions against glutamate-induced excitotoxicity. Finally, the effects of lithium to attenuate stimulus-induced $\mathrm{Ca}^{2+}$ mobilization at the same time as elevating resting levels recalls the 'bimodal hypothesis' (Jope, 1999) that lithium normalizes the balance between positive and negative regulators of intracellular signal transduction processes, thereby stabilizing and maintaining their function within an optimal range. In this context, $\mathrm{Ca}^{2+}$ signaling modulates gene expression and protein function through spatially regulated changes in frequency and amplitude of intracellular $\mathrm{Ca}^{2+}$ waves (Ghosh and Greenberg, 1995). Stabilization of fluctuations in intracellular $\mathrm{Ca}^{2+}$ levels by lithium could significantly modify the transcriptional regulation and expression of key neuronal proteins that, in turn, correct aberrant neuronal activity in critical brain regions involved in mood regulation. As the integrity of intracellular $\mathrm{Ca}^{2+}$ homeostasis is critical to cell survival, these effects of lithium on $\mathrm{Ca}^{2+}$ signaling processes may also be relevant mechanistically to its neuroprotective effects, now thought to be important in the clinical action of this agent (Manji et al, 2000).

In conclusion, the findings of the current study suggest that chronic lithium treatment modifies processes that impact on intracellular $\mathrm{Ca}^{2+}$ signaling and homeostasis. Taken together with our recent report suggesting $\mathrm{Ca}^{2+}$ signaling may be hyperactive in BLCLs from patients with
BD (Wasserman et al, 2003), a cellular model that may report disturbances particularly relevant to the pathophysiology of this disorder, these observations suggest that the regulation of intracellular $\mathrm{Ca}^{2+}$ homeostasis may be especially pertinent to the therapeutic action of lithium. In this regard, lithium's modulation of intracellular $\mathrm{Ca}^{2+}$ signaling, be it direct or indirect, could have important implications in terms of stabilizing gene expression, cellular communication, and perhaps excitotoxic or apoptotic cell death.

\section{ACKNOWLEDGEMENTS}

A preliminary report of this work was presented at the 57th annual meeting of the Society for Biological Psychiatry, Philadelphia, PA. This work was supported by the Canadian Institutes of Health Research (grants MOP12851 (JJW) and MOP53323 (JJW and PPL)). MJW is a recipient of a Research Studentship from the Ontario Mental Health Foundation and TWC was supported by a Natural Sciences \& Engineering Research Council postgraduate scholarship and University of Toronto scholarship. We gratefully acknowledge the contributions of the physicians and research staff at the Centre for Addiction and Mental Health for their assistance in recruiting potential patient subjects for participation in these studies. Arvind Kamble and Kin Po Siu contributed to the technical laboratory aspects of this work and Bronwen Hughes in the clinical data collection and analysis.

\section{REFERENCES}

Andreopoulos S, Wasserman MJ, Li PP, Warsh JJ (2003). Bipolar disorder-specific reduction of transient receptor potential channel-3 levels in B lymphoblasts exposed chronically to lithium. Bipolar Disord 5: 29.

Barritt GJ (1999). Receptor-activated $\mathrm{Ca}^{2+}$ inflow in animal cells: a variety of pathways tailored to meet different intracellular $\mathrm{Ca}^{2+}$ signaling requirements. Biochem J 337: 153-169.

Berk M, Bodemer W, Oudenhove TV, Butkow N (1995). The platelet intracellular calcium response to serotonin is augmented in bipolar manic and depressed patients. Hum Psychopharmacol 10: 189-193.

Berridge MJ (1995). Inositol trisphosphate and calcium signaling. Ann NY Acad Sci 766: 31-43.

Berridge MJ, Downes CP, Hanley MR (1982). Lithium amplifies agonist-dependent phosphatidylinositol responses in brain and salivary glands. Biochem J 206: 587-595.

Berridge MJ, Lipp P, Bootman MD (2000). The versatility and universality of calcium signaling. Nat Rev Mol Cell Biol 1: 11-21.

Blaustein MP, Lederer WJ (1999). Sodium/calcium exchange: its physiological implications. Phys Rev 79: 763-854.

Brini M, Carafoli E (2000). Calcium signaling: a historical account, recent developments and future perspectives. Cell Mol Life Sci 57: $354-370$.

Chang A, Li PP, Warsh JJ (2002). cAMP signal transduction in the pathophysiology of mood disorders: contributions from postmortem studies. In: Agam G, Everall IP, Belmaker RH (eds). The Postmortem Brain in Psychiatric Research. Kluwer Academic Publishers: Boston. pp 341-361.

Choi SJ, Xia Z, Villacres EC, Storm DR (1993). The regulatory diversity of the mammalian adenylyl cyclases. Curr Opin Cell Biol 5: 269-273. 
Cooper DM, Mons N, Karpen JW (1995). Adenylyl cyclases and the interaction between calcium and cAMP signaling. Nature 347: 421-424.

Dubovsky SL, Christiano J, Daniell LC, Franks RD, Murphy J, Adler L et al (1989). Increased platelet intracellular calcium concentration in patients with bipolar affective disorders. Arch Gen Psychiatry 46: 632-638.

Dubovsky SL, Lee C, Christiano J, Murphy J (1991). Lithium decreases platelet intracellular calcium concentration in bipolar patients. Lithium 2: 167-174.

Dubovsky SL, Murphy J, Thomas M, Rademacher J (1992). Abnormal intracellular calcium ion concentration in platelets and lymphocytes of bipolar patients. Am J Psychiatry 149: 118-120.

Dubovsky SL, Thomas M, Hijazi A, Murphy J (1994). Intracellular calcium signaling in peripheral cells of patients with bipolar affective disorder. Eur Arch Psychiatry Clin Neurosci 243: 229-234.

Emamghoreishi M, Schlichter L, Li PP, Parikh S, Sen J, Kamble A et al (1997). High intracellular calcium concentrations in transformed lymphoblasts from subjects with bipolar I disorder. Am J Psychiatry 154: 976-982.

Fall CP, Keizer JE (2001). Mitochondrial modulation of intracellular $\mathrm{Ca}(2+)$ signaling. $J$ Theor Biol 210: 151-165.

First M, Spitzer R, Gibbon M, Williams JBW (1995a). Structured Clinical Interview for DSM-IV Axis I Disorders-Nonpatient Edition (SCID-I/NP, Version 2.0). Biometrics Research Department, New York Psychiatric Institute: New York, NY.

First M, Spitzer RL, Robert L, Gibbon M, Williams JBW (1995b). Structured Clinical Interview for DSM-IV Axis I Disorders-Patient Edition (SCID-I/P, Version 2.0). Biometrics Research Department, New York State Psychiatric Institute: New York, NY.

Forstner U, Bohus M, Gebickeharter PJ, Baumer B, Berger M, Van Calker D (1994). Decreased agonist-stimulated $\mathrm{Ca}^{2+}$ response in neutrophils from patients under chronic lithium therapy. Eur Arch Psychiatry Clin Neurosci 243: 240-243.

Galas MC, Harden TK (1997). Cyclic AMP-induced desensitization of G-protein-regulated phospholipase C in turkey erythrocyte membranes. Eur J Pharmacol 314: 157-164.

Gelenberg AJ, Carroll JA, Baudhuin MG, Jefferson JW, Greist JH (1989). The meaning of serum lithium levels in maintenance therapy of mood disorders: a review of the literature. J Clin Psychiatry 50(Suppl): 17-22.

Ghosh A, Greenberg ME (1995). Calcium signaling in neurons: molecular mechanisms and cellular consequences. Science 268: 239-247.

Goodwin FK, Jamison KR (1990). Manic-Depressive Illness. Oxford University Press: New York.

Grynkiewicz G, Poenie M, Tsien RY (1985). A new generation of $\mathrm{Ca}^{2+}$ indicators with greatly improved fluorescence properties. J Biol Chem 260: 3440-3450.

Hajnoczky G, Gao E, Nomura T, Hoek JB, Thomas AP (1993). Multiple mechanisms by which protein kinase A potentiates inositol 1,4,5-trisphosphate-induced $\mathrm{Ca}^{2+}$ mobilization in permeabilized hepatocytes. Biochem J 293: 413-422.

Hallcher LM, Sherman WR (1980). The effects of lithium ion and other agents on the activity of myo-inositol-1-phosphatase from bovine brain. J Biol Chem 255: 10896-10901.

Hashimoto R, Hough C, Nakazawa T, Yamamoto T, Chuang DM (2002). Lithium protection against glutamate excitotoxicity in rat cerebral cortical neurons: involvement of NMDA receptor inhibition possibly by decreasing NR2B tyrosine phosphorylation. J Neurochem 80: 589-597.

Helman J, Kuyatt BL, Takuma T, Seligmann B, Baum BJ (1986). ATP-dependent calcium transport in rat parotid basolateral membrane vesicles. Modulation by agents which elevate cyclic AMP. J Biol Chem 261: 8919-8923.
Hough C, Lu S-J, Davis CL, Chuang D-M, Post RM (1999). Elevated basal and thapsigargin-stimulated intracellular calcium of platelets and lymphocytes from bipolar affective disorder patients measured by a fluorometric microassay. Biol Psychiatry 46: 247-255.

Hudson CJ, Young LT, Li PP, Warsh JJ (1993). CNS transmembrane signal transduction in the pathophysiology and pharmacology of affective disorders and schizophrenia. Synapse 13: 278-293.

Jope RS (1999). A bimodal model of the mechanism of action of lithium. Mol Psychiatry 4: 21-25.

Jope RS, Song L, Li PP, Young LT, Kish SJ, Pacheco MA et al (1996). The phosphoinositide signal transduction system is impaired in bipolar affective disorder brain. J Neurochem 66: 2402-2409.

Jope RS, Williams MB (1994). Lithium and brain signal transduction systems. Biochem Pharmacol 47: 429-441.

Kato T, Shioiri T, Inubushi T, Takahashi S (1993). Brain lithium concentrations measured with lithium-7 magnetic resonance spectroscopy in patients with affective disorders - relationship to erythrocyte and serum concentrations. Biol Psychiatry 33: 147-152.

Kusumi I, Koyama T, Yamashita I (1994). Serotonin-induced platelet intracellular calcium mobilization in depressed patients. Psychopharmacology (Berl) 113: 322-327.

Lenox RH, Gould TD, Manji HK (2002). Endophenotypes in bipolar disorder. Am J Med Genet 114: 391-406.

Lenox RH, McNamara RK, Papke RL, Manji HK (1998). Neurobiology of lithium: an update. J Clin Psychiatry 59(Suppl 6): 37-47.

Manji HK, McNamara R, Chen G, Lenox RH (1999). Signaling pathways in the brain: cellular transduction of mood stabilization in the treatment of manic-depressive illness. Aust NZ J Psychiatry 33(Suppl): S65-S83.

Manji HK, Moore GJ, Chen G (2001). Bipolar disorder: leads from the molecular and cellular mechanisms of action of mood stabilizers. Br J Psychiatry 41(Suppl): s107-s119.

Manji HK, Moore GJ, Rajkowska G, Chen G (2000). Neuroplasticity and cellular resilience in mood disorders. Mol Psychiatry 5: 578-593.

Masana MI, Bitran JA, Hsiao JK, Potter WZ (1992). In vivo evidence that lithium inactivates $G_{i}$ modulation of adenylate cyclase in brain. J Neurochem 59: 200-205.

Mattson MP (2000). Apoptosis in neurodegenerative disorders. Nat Rev Mol Cell Biol 1: 120-129.

Nonaka S, Hough CJ, Chuang DM (1998). Chronic lithium treatment robustly protects neurons in the central nervous system against excitotoxicity by inhibiting $N$-methyl-D-aspartate receptor-mediated calcium influx. Proc Natl Acad Sci USA 95: 2642-2647.

Nuccitelli R (1994). Methods in Cell Biology, Volume 40: A Practical Guide to the Study of Calcium in Living Cells. Academic Press: New York.

Okamoto Y, Kagaya A, Motohashi N, Yamawaki S (1995). Inhibitory effects of lithium ion on intracellular $\mathrm{Ca}^{2+}$ mobilization in the rat hippocampal slices. Neurochem Int 26: 233-238.

Ozaki N, Chuang DM (1997). Lithium increases transcription factor binding to AP-1 and cyclic AMP-responsive element in cultured neurons and rat brain. J Neurochem 69: 2336-2344.

Patel S, Joseph SK, Thomas AP (1999). Molecular properties of inositol 1,4,5-trisphosphate receptors. Cell Calcium 25: 247-264.

Perez J, Tardito D, Mori S, Racagni G, Smeraldi E, Zanardi R (2000). Abnormalities of cAMP signaling in affective disorders: implication for pathophysiology and treatment. Bipolar Disord 2: 27-36.

Plenge P, Stensgaard A, Jensen HV, Thomsen C, Mellerup ET, Henriksen O (1994). 24-hour lithium concentration in human 
brain studied by Li-7 magnetic resonance spectroscopy. Biol Psychiatry 36: 511-516.

Putney JW, Broad LM, Braun FJ, Lievremont JP, Bird GS (2001). Mechanisms of capacitative calcium entry. J Cell Sci 114: 22232229.

Putney JW, Ribeiro CM (2000). Signaling pathways between the plasma membrane and endoplasmic reticulum calcium stores. Cell Mol Life Sci 57: 1272-1286.

Rasmussen H (1986). The calcium messenger system (1). N Engl J Med 314: 1094-1101.

Rosskopf D, Daelman W, Busch S, Schurks M, Hartung K, Kribben A et al (1998). Growth factor-like action of lysophosphatidic acid on human B lymphoblasts. Am J Physiol 274: C1573-C1582.

Schou M (1968). Lithium in psychiatric therapy and prophylaxis. J Psychiatr Res 6: 67-95.

Schou M (2001). Lithium treatment at 52. J Affect Disord 67: 21-32. Supattapone S, Danoff SK, Theibert A, Joseph SK, Steiner J, Snyder SH (1988). Cyclic AMP-dependent phosphorylation of a brain inositol trisphosphate receptor decreases its release of calcium. Proc Natl Acad Sci USA 85: 8747-8750.

Szalai G, Krishnamurthy R, Hajnoczky G (1999). Apoptosis driven by IP(3)-linked mitochondrial calcium signals. EMBO J 18: 63496361.

Tan CH, Javors MA, Seleshi E, Lowrimore PA, Bowden CL (1990). Effects of lithium on platelet ionic intracellular calcium concentration in patients with bipolar (manic-depressive) disorder and healthy controls. Life Sci 46: 1175-1180.

Varney MA, Godfrey PP, Drummond AH, Watson SP (1992). Chronic lithium treatment inhibits basal and agonist-stimulated responses in rat cerebral cortex and GH3 pituitary cells. Mol Pharmacol 42: 671-678.

Wang HY, Friedman E (1999). Effects of lithium on receptormediated activation of $\mathrm{G}$ proteins in rat brain cortical membranes. Neuropharmacology 38: 403-414.

Wang L, Liu X, Lenox RH (2001). Transcriptional down-regulation of MARCKS gene expression in immortalized hippocampal cells by lithium. J Neurochem 79: 816-825.

Wasserman MJ, Warsh JJ, Li PP, Pennefather P, Sibony D (2003). Hyperactive intracellular calcium mobilization in B lymphoblasts from patients with bipolar I disorder. Biol Psychiatry 53(Suppl): 79S.

Williams RS, Harwood AJ (2000). Lithium therapy and signal transduction. Trends Pharmacol Sci 21: 61-64.

Yamaji T, Kagaya A, Uchitomi Y, Yokota N, Yamawaki S (1997). Chronic treatment with antidepressants, verapamil, or lithium inhibits the serotonin-induced intracellular calcium response in individual C6 rat glioma cells. Life Sci 60: 817-823.

Yoon I-S (2002). Molecular analysis of altered calcium homeostas in bipolar disorder using differential and candid geno approach. PhD Thesis, University of Toronto.

Yoon IS, Li PP, Siu KP, Kennedy JL, Cooke RG, Parikh SV et al (2001a). Altered IMPA2 gene expression and calcium homeostasis in bipolar disorder. Mol Psychiatry 6: 678-683.

Yoon IS, Li PP, Siu KP, Kennedy JL, Macciardi F, Cooke RG et al (2001b). Altered TRPC7 gene expression in bipolar-I disorder. Biol Psychiatry 50: 620-626. 